\title{
TELEMETRICAL INFORMATION EVALUATION ABOUT GEOPHYSICAL PROCESSES AT CONDITIONS OF NOISE
}

Kupriyanov V. V. - Dr. Sc., Professor, Department of Automated Control Systems, National University of Science and Technology «MISIS», Moscow, Russia.

\section{ABSTRACT}

Context. The problem of minimizing information losses during discrete measurement of methane content during the extraction of coal in coal mines is considered.

Objective. The object of the study was the methodology for assessing the loss of telemetric information about geophysical processes in mines under noise conditions. The purpose of the work is to create a set of discrete and block schemes for obtaining information to assess its losses in the presence of distortions based on an information approach.

Method. The results of a study of the methodology for solving the problem of minimizing information loss when measuring methane content in coal mines are presented. A measure of distortions arising from the discrete display of the set of states of the geophysical process in the measurement space under noise and error conditions in the elements of the automated methane control subsystem is proposed. Along with this measure, a model is also proposed for determining the lower boundary of the expected information for given distortions, based on the solution of the optimization problem. The characteristics of some discrete and block schemes for obtaining information are investigated. The proposed block schemes take into account the grouping of transition probability values in three, five, seven, ten, and fifteen-dimensional versions. By varying the size of the grouping in blocks, the technique allows one to obtain various levels of detail of the boundaries of the expected information.

Results. The developed schemes were implemented in software and investigated to solve the problem of minimizing information loss while monitoring methane contents in coal mines.

Conclusions. The experiments carried out confirmed the operability of the proposed software and allow us to recommend it for use in practice when constructing $n$-dimensional schemes for obtaining information. Prospects for further research may lie in an experimental study of the proposed schemes on a larger set of practical tasks of a different nature, as well as in the creation of promising measuring systems based on the principles of information analysis.

KEYWORDS: discrete scheme for obtaining information, distortion, transition probability, information loss, noise.

\section{NOMENCLATURE}

$\alpha$ is a number of equally probable states of the geophysical process;

$\beta$ is some constant distortion dependent;

$\gamma$ is a parameter, characterizing the amount of distortion and varying from 0 to $\infty$;

$\delta_{i j}$ is some value, taking value 1 or 0 ;

$\lambda_{i j}$ is a value, varying from 0 to $1,0 \leq \lambda \leq 1$;

$\varepsilon_{\min }, \varepsilon_{\max }$ are minimum and maximum distortion values, respectively;

$\varepsilon_{i j}$ is a element of square distortion matrix;

$\bar{\varepsilon}$ are the mean distortions at measurements;

$\bar{\varepsilon}_{0}$ are the возможные искажения according to Bellman measurement technique;

$\varepsilon_{1}, \varepsilon_{2}, \varepsilon_{3}$ are the distortions, arising at the transition probabilities $q_{1}, q_{2}, q_{3}$ accordingly;

$C_{0}$ is an optimal measurement method based on the Bellman maximum principle;

$C_{E}$ is an $\varepsilon-$ optimal measurement procedure

$E$ is a distortion matrix;

$I(X)$ is an information quantity about state of geophysical process;

$I(Z, X)$ is an amount of expected (received) information during measurements $k_{j}$;

$I[q(j \mid i)]$ is an average mutual information between $i$ and $j$;
$M$ is math operator;

$P_{i}=p(i)$ is a probability of the $i$-th state of the geophysical process;

$P_{i j}=p(i j)$ is a probability of information loss;

$q(i \mid j)$ is a conditional probability of transition from $i$ to $j$;

$\|t k l\|$ is an inverse matrix $\left\|p_{k j}\right\|$;

$\sum_{k} t k l p_{k j}$ is an identity matrix whose elements are equal 1 at $\mathrm{l}=j$ и 0 otherwise;

$x_{i}, x_{j}$ are the values of the $i$-th state of the geophysical process.

\section{INTRODUCTION}

As is known [1, 2], all measured quantities are considered to be changing randomly, especially under conditions of interference, fluctuations, and noise, from which not a single measurement is free. Therefore, for each individual measurement, we are dealing with only one random implementation. It is possible to evaluate a random variable or process only by statistical methods. This requires knowledge of the law of distribution or, at least, some characteristics, for example, the first and second moments, which depend on the type of distribution function. Therefore, in order to obtain information based on any measurements, the available data must be statistically processed. It is generally believed that a certain averaging is already achieved during measurements using inertial 
measuring instruments. In the case when the measured implementation consists of a regular component and a random component completely determined by noise or random noise-like errors, the measuring device or system will give an increasingly reliable value of the measured value over time. But, when instead of the regular component we have a random one, such a measurement will lead to a loss of information.

Conventional measuring devices can give only some idea of the mathematical expectation of a random implementation. Statistical estimation of a real random process is possible only for an ensemble of realizations. All conventional measuring devices and systems in the process of the aforementioned averaging filter out not only the interference, but at the same time some of the information. So, there is a loss of information that cannot be compensated for by any measures, such as an increase in measurement time. To solve this problem, it is necessary to use other criteria, in particular, the criterion of sufficiency of statistics. In this paper, we consider the case of estimating additional information losses caused by noise, measurement errors and transformations.

This assessment is an important step in constructing discrete schemes for obtaining information. The very purpose of these systems as a tool for obtaining information, always flowing under conditions of noise and interference, determines the interest that is the study of the criteria for optimizing measurements at a particular level of distortion [1]. This task is relevant for the processing of telemetric data on the parameters of general-purpose processes, including the parameters of geophysical processes, in particular, the concentration of methane and dust in coal mines.

The object of study is a process of investigation characters of different schemes of information receipt about the methane maintain in mines to reduce her losses in condition of noises.

The estimation of these losses is associated with the presence of distortions caused by both measurement errors and information transformations in the automated methane control subsystem. Therefore, to reduce the losses of information it is necessary to build the schemes of her receipt, providing the reduction of probability errors measuring, without resorting to the use of certain special devices.

The subject of study is the characters of discrete and block schemes of telemetrically information receipt. The known schemes are characterized by the enough large losses of information, and, therefore, the errors measuring, as well as characterized by the uncertainty of quality criteria of measurements optimization.

The purpose of the work is to reduce the additional losses of telemetric information, caused by noise, measurement errors and transformed to build the schemes if information receipt about the methane maintain at the presence of distortions.

\section{PROBLEM STATEMENT}

Suppose given the measure of distortion arising from discrete display of the set $\mathrm{X}$, describing the state of the geophysical process into the measurement space $\mathrm{Z}$, due to interference and errors in the elements of the methane control system as on matrix of distortion $E=\| \varepsilon_{i j} \mid, i, j$ $=1,2, \ldots, n$, where

$$
\varepsilon_{i j}=1-\delta_{i j} ; \delta_{i j}=1 \text {, if } i=j ; \delta_{i j}=0 \text {, if } i \neq j .
$$

Each element of this matrix corresponds to the loss of information that appears during its transformation with an error, when each $x_{j}$. Then the average loss of information that occurs in this case is equal to:

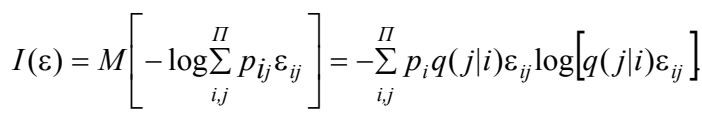

Given the loss of information (1), the expected information that can be obtained and implemented as a result of measurements and transformations is determined by the expression:

$$
M\{I(x)-I(\varepsilon)\} .
$$

For the given formulas (1), (2) the problem of additional losses of information minimization can be presented as the problem of finding $M\{I(x)-I(\varepsilon)\} \rightarrow \max$, where the model structure $M I(x)$ specified by formula:

$$
M I(x)=\sum_{i, j}^{n} p_{i} q(j \mid i) \log \left[\frac{q(j \mid i)}{\sum_{k}^{m} p_{k} q(j \mid k)}\right], m<n .
$$

This problem is to find the optimality conditions for discrete measurements at given distortions. In turn, the problems of an extreme probability $p_{i}$ definition and lower boundaries of expected information, her losses finding are a consequence of the proposed measurement optimality condition.

\section{REVIEW OF THE LITERATURE}

A sufficient number of publications is known regarding assessments of the value of various sources of information, the magnitude of information loss during transmission, reception and processing [1-15]. For example, there are characteristics of the throughput of one or another real system with information distortions, in particular, at 10 or $50 \%[3,6]$. You can imagine and take off such characteristics of the system in case of distortion. To do this, compare the information at the input and output of the system and, if its output is half as much, then the distortion is $50 \%$. According to this principle, the work of all modern modems is evaluated. But analytically such an informational characteristic is difficult to imagine using the Shannon entropy measure [2]. For this purpose, it is 
more convenient to use the epsilon-entropy measure of A. N. Kolmogorov, based on estimating the amount of information received at its input per unit of time [4]. In fact, measurement accuracy is always limited. Therefore, the requirement of infinite accuracy of reproduction of a continuous quantity by any source is unrealistic. Measurement accuracy should be limited to a certain value, depending on the level of interference. In information theory, it is believed that two implementations that differ by an amount not greater than some given value are perceived as signals that carry exactly the same information.

It was shown in [6] that the level of distortion determines part of the spectrum of the measured signal that is not observed by the system, and epsilon-entropy allows you to specify the amount of information at the input of the measurement system at which a given level of distortion is provided. Filing more information per unit time than what is determined by the epsilon-entropy estimate is irrational. As a rule, in practice this condition is not fulfilled. So, when using the amplitude - time language, the error is representable only in this language. Therefore, the main question: how to present a system error for any language? If the information is presented in a letter count, then the concept of error disappears. In this regard, the concept of the reliability of information for different languages was introduced, which is very difficult $[1,3]$.

To date, methods have been developed to evaluate the characteristics of information acquisition systems under the conditions of noise and noise [8, 16, 18]. But these methods are rather laborious and can lead to sufficiently large errors. It is necessary to exercise some caution when choosing the characteristics of the schemes for obtaining information using these methods. This is due to the fact that they did not take into account additional losses due to the conversion of information from the space describing the state of the process under study into the measurement space.

Summarizing what has been said, we can say that the issues of assessing information loss that occur during its transformation in the elements of measurement systems that themselves work with errors, with the inherent presence of random noise, are not given due attention. Almost all authors agree with the presence of information loss during measurements. It is often believed that these losses occur due to limitations in the description of processes, i.e. with a reduction in the volume of characteristics characterizing them or their low information content. Under the conditions of the random nature of external influences, sufficient statistics are needed to obtain reliable estimates of the parameters of a process or object. The latter can be determined by stabilizing the law of distribution of random variables. To select such statistics, it is necessary to investigate a number of typical processes or objects. You can use the information analysis of the research results of the process described using a multivariate model with a polynomial distribution of random variables [17]. Having a finite total number of independent dimensions, already in the three-factor model, each dimension will correspond to the values of three variables,

(C) Kupriyanov V. V., 2020

DOI 10.15588/1607-3274-2020-4-3 row, column, and depth attributes of a three-dimensional matrix with different dimensions. The information components for the row, column, depth are calculated. The probability of the total experimental error is estimated, but no more. This method is quite complicated and can lead to loss of information.

\section{MATERIALS AND METHODS}

It is easy to verify that, based on (1), (2), the optimality condition for measurements reduces to maximizing the amount of expected information

$$
I(Z, X)=M\{I(X)-I(\varepsilon)\} .
$$

It is established that in the presence of noise and errors in the measuring system, the measurement procedure $C_{0}$, optimal according to the Bellman maximum principle [19], is unattainable for any positive values $\varepsilon_{j}$. Therefore, it was concluded that with information loss $I(\varepsilon)$, always present in real conditions, we can only talk about some measurement procedure $C_{E}=C_{0}-E$, which we define as $\varepsilon$-optimal if it is selected according to (4) from the condition of minimum losses $I(\varepsilon)$. We will consider such optimization as optimization for a given level of distortion. For its implementation, it is necessary to find, if it exists, the relationship between the expected information and its losses. In terms of meaning, such optimization is closely correlated with the epsilon-entropy measurement optimization procedure [13]. Applying it, as well as the classical scheme of C. Shannon [2], taking into account that $I[q(j \mid i)]$ is a function of $q(j \mid i)$ in the entire measurement area, it is possible to find that the average mutual information between $i$ and $j$, calculated by the formula (3), corresponds to the value:

$$
I[q(j \mid i)]=\min M\{I[q(j \mid i)]\} .
$$

With medium distortion $\bar{\varepsilon}>\bar{\varepsilon}_{0}$.

Insofar as $I[q(j \mid i)]$ is a convex upward function of transition probabilities $q(j \mid i)$, but $I(\varepsilon)$ as a function $q(j \mid i)>0$ и $\varepsilon_{i j}>0$ is convex downward, due to the linear relationship between $q(j \mid i)$ and $\varepsilon_{i j}$ it can be argued that function (4) is a monotone, strictly convex function $\varepsilon_{i j}$. This is easy to verify if, for two arbitrary values $\varepsilon_{1}$ and $\varepsilon_{2}$ find linear relationship

$$
\varepsilon_{3}=\alpha \varepsilon_{1}+(1-\alpha) \varepsilon_{2} .
$$

Function (4) lies entirely below the segment (5) connecting its two mismatched points $\varepsilon_{1}$ and $\varepsilon_{2}$. 
I take into account that for a fixed value $\varepsilon_{3}$ the condition is satisfied

$$
\min M\left\{I\left(\varepsilon_{3}\right)\right\} \leq I(Z, X)
$$

it can be argued that function (4) is convex down. Thus, the general character of function (4) was determined. For each $j$, there is some value $\varepsilon_{i j}$. If for each the condition

$$
\max _{j} q(j \mid i)=1,
$$

then $\varepsilon_{i j}$ take values $\max _{i} \varepsilon_{i j}$. Then we get

$$
\varepsilon_{\min }=\sum_{i}^{n} p_{i} \min \varepsilon_{i j} .
$$

In this case, it is not difficult to find difficulties. Searching for values $I\left(\varepsilon_{\min }\right)$. If $q(i \mid j)=F_{j}$, then $(Z, X)=0$, moreover, for each $j$ the loss of information is equal to

$$
\log \sum_{j}^{n} F_{j} \sum_{i}^{n} p_{i} \varepsilon_{i j}
$$

At $F_{j}=1$ minimum information loss for a given $I_{j}$ corresponds to $\min _{j} \sum_{i}^{n} p_{i} \varepsilon_{i j}$. But the option is possible when $\varepsilon_{\max }=\min _{j} \sum_{i}^{n} p_{i} \varepsilon_{i j}$.

This distortion value corresponds to the maximum loss of information.

$$
I\left(\varepsilon_{\max }\right)=M\left\{-\operatorname{logmin}_{j} \sum_{i}^{n} p_{i} \varepsilon_{i j}\right\} .
$$

Based on these considerations, one can graphically represent the general nature of the dependence of the received or expected information on its losses in the form shown in Fig. 1.

$$
I(Z, X)=\sum_{i, j}^{n} p_{i} p(i \mid j) \log \frac{p(i \mid j)}{\sum_{j} p_{i} p(i \mid j)} .
$$

The values of $p_{i}$ delivering maximum functions (7) were found using Lagrange multipliers with restrictions:

$$
\sum_{i}^{n} p_{i}=1 ; 0 \leq p_{i} \leq 1 .
$$

As a result, expressions were obtained for determining the extreme value $p_{i}$ :

$$
p_{i}=\sum_{i} t_{i l} \exp \left[-I(Z, X) \sum_{k} t_{k l}+\sum_{k, l} t_{k l} p_{k l} \log p_{k l}\right]
$$

It is found that for $\varepsilon=\varepsilon_{\max }$ value $I(Z, X)_{\min } \rightarrow 0$.

It is found that for $I(Z, X)$ for the case when different concentrations of methane $x_{1}, x_{2}, \ldots, x_{n}$ in the geophysical process is an equally probable event, i.e. the probability of any of them $p_{i}=\frac{1}{n}$. Matrix $\left\|\varepsilon_{i j}\right\|$-square. Its rows and columns consist of the same set of elements. $\varepsilon_{1}, \varepsilon_{2}, \ldots, \varepsilon_{n}$ arranged in different order. In this case, with minimizing values $q\left(\frac{J}{i}\right)$ all conditional transitions with equal distortion values $\varepsilon$ have the same probabilities. Transition probabilities $q\left(\frac{J}{i}\right)$ correlated distortion $\varepsilon_{i j}$.

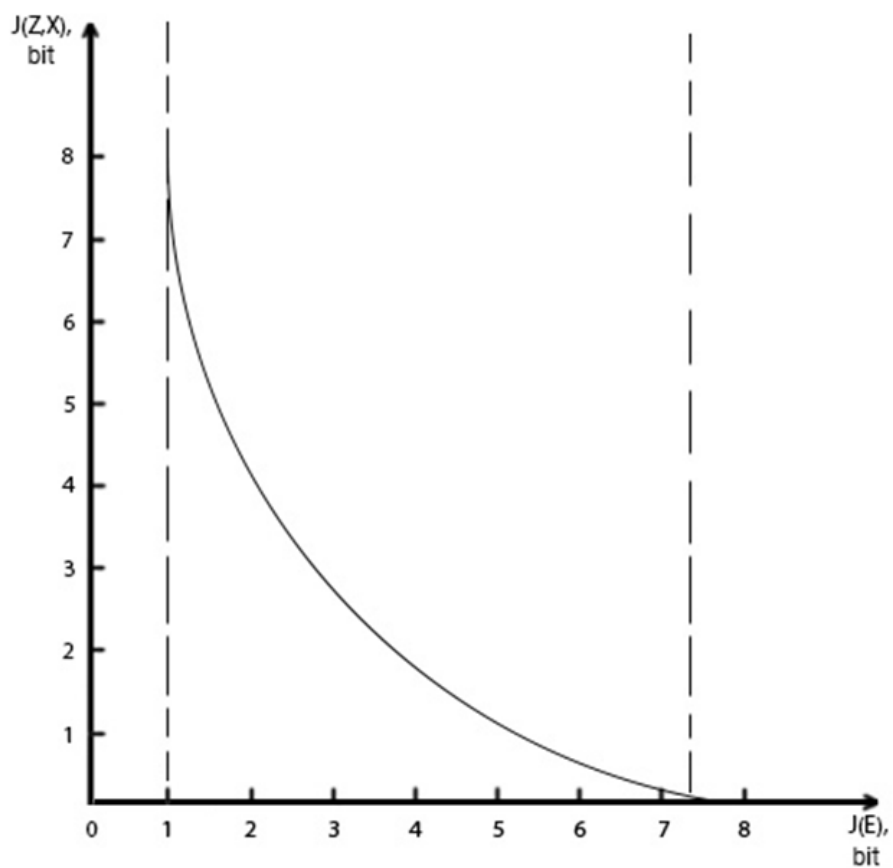

Figure 1 - Dependence of Expected Information $I(Z, X)$ when measuring from its losses $I(\varepsilon)$ 
Under these conditions, the lower limit of the values of the information obtained at its given distortions can be found by externalizing the expression:

$$
I(Z, X)=\log n+\sum_{i} q_{i} \log q_{i}
$$

with restrictions on average information loss

$$
\sum_{i} q_{i} \varepsilon_{i} \log \left(q_{i} \varepsilon_{i}\right)>0, \varepsilon_{i}>0,-1 \leq q_{i} \leq 1
$$

Using the method of the Lagrange set, we obtained a solution to this optimization problem, which has the form:

$$
I(Z, X)=\left(\gamma \gamma_{i} \log \varepsilon_{i}\right) /\left(1+\gamma \varepsilon_{i}\right)
$$

For small and very large values of the parameter $\gamma$, expression (9) can be simplified by performing a series of transformations. However, we do not give them because of their bulkiness. For us, the relationships are fundamentally important $\gamma=0$ and $\gamma=\infty$.

$$
\text { At } \gamma=0 I(Z, X)=0 \text {, }
$$

but at $\gamma=\infty I(Z, X)=\log n-\beta, \beta>1$.

Similarly, the formulas for calculating information loss are given, namely:

$$
\begin{aligned}
& \text { At } \gamma=0 \quad I(\varepsilon)=\frac{1}{2} \sum_{i}^{n} \varepsilon_{i}\left(\log \sum_{i}^{n} \varepsilon_{i}-\log n\right), \\
& \text { at } \gamma=\infty I(\varepsilon) \rightarrow I_{\text {min }}(\varepsilon) .
\end{aligned}
$$

\section{EXPEREMENTS}

To assess the correctness of the proposed methodology and on its basis the found characteristics of some discrete and block systems for obtaining information, taking into account losses using the standard Shannon method of forming the simplest such schemes [2]. The computer program implementing the proposed method was implemented using the Python programming language and was developed to conduct experiments. This softtion of the losses of information at the methane maintain control of meaning. As the initial data, we took methanograms obtained during the extraction of the angle in the coal mines of the Russian Federation. Processing of methanograms was carried out on the basis of generally accepted technology for processing experimental data [14, 20]. It relies on the use of information redundancy in the parameters and includes a number of simplified algorithms that work in the presence of abnormal sections (outliers of controlled parameters, omissions in current records of methanograms [21, 22].
Discrete circuits were formed by expanding the simplest binary. In block schemes, some points were sought by randomly generating combinations of their values based on known adjacent schemes [6]. The signals are implemented in the form of a sequence of samples spaced from each other at intervals of the interrogation of the control equipment in the range from 3 to 10 minutes. The frequency of the survey usually exceeds the requirements of the Kotelnikov theorem. Methanogram recording sections up to 54 samples long were processed.

\section{RESULTS}

The results of conducted experiments are presented at the Fig. 2 and Fig. 3. Fig. 2 graphically illustrates the change of expected information depending on the probability of its loss $p(E)$ or various numbers (2 - binary, 3 ternary, 4 - quaternary, 5 - quaternary and so on) of equally probable values $x_{i}$. In fact, these numbers reflect the densities of equiprobable values $x_{i}$ a binary discrete circuit with equally probable values $x_{i}(i=1,2)$, for which we have

$$
\begin{gathered}
J(Z, X)=1+E \times \log E+(1-E) \log (1-E), \\
q(j / i)=E, q(i / j)=1-E .
\end{gathered}
$$

For such circuits, the value $J(Z, X)=1$ bit corresponds to $E=0$ и $p(E)=0$. It is provided by simultaneous measurement of both values $x_{i}$. Curves 3, 4, 5, 10, 50 relate to schemes formed from the corresponding series of numbers of equally probable values $x_{i}$. For example, following C. Shannon, the function corresponding to our $J(Z, X)$, in situation $\alpha$ uniform values $x_{i}$, is equal to:

$$
J(Z, X, \alpha)=\log \alpha+E \times \log E+(1-E) \log \frac{1-E}{\alpha-1} .
$$

At Fig. 3 information change dependencies are shown $J(Z, X, \alpha)$ от вероятности ее потерь $p(E)$ при блочных схемах формирования информации. Curve A relates to a conventional binary circuits. Curve B describes an integrated information retrieval block scheme in which blocks of probability values are grouped with some redundancy, which corresponds to the Shannon style. For example, a five-dimensional scheme in which the blocks correspond to the values of the transition probabilities $x_{i}(i=1,2, \ldots, 5)$, corresponds to the probability $p(E)=0.2$. The ten-dimensional scheme corresponds to a probability equal to 0.1 . For a fifteen-dimensional scheme, we have $p(E)=0.067$. 


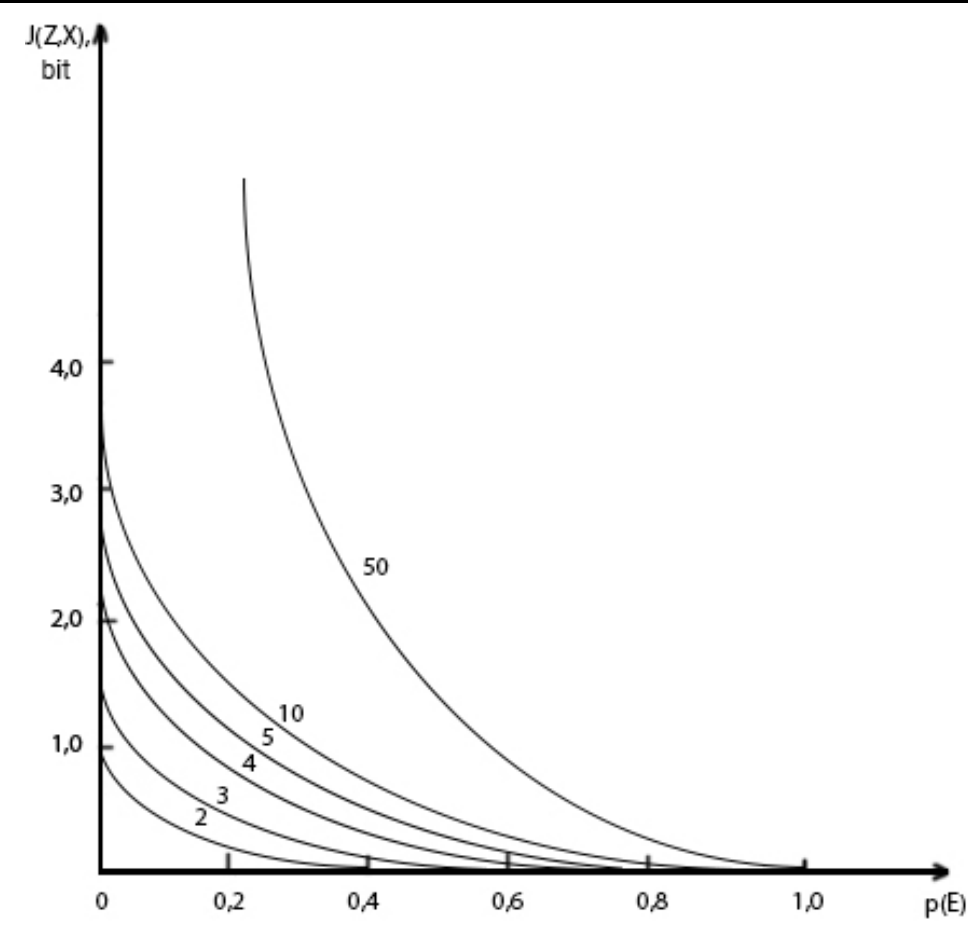

Figure 2 - Curves of changes in expected information $J(Z, X)$ from the probability of her loss $p(E)$ for various discrete receiving schemes $x_{i}$

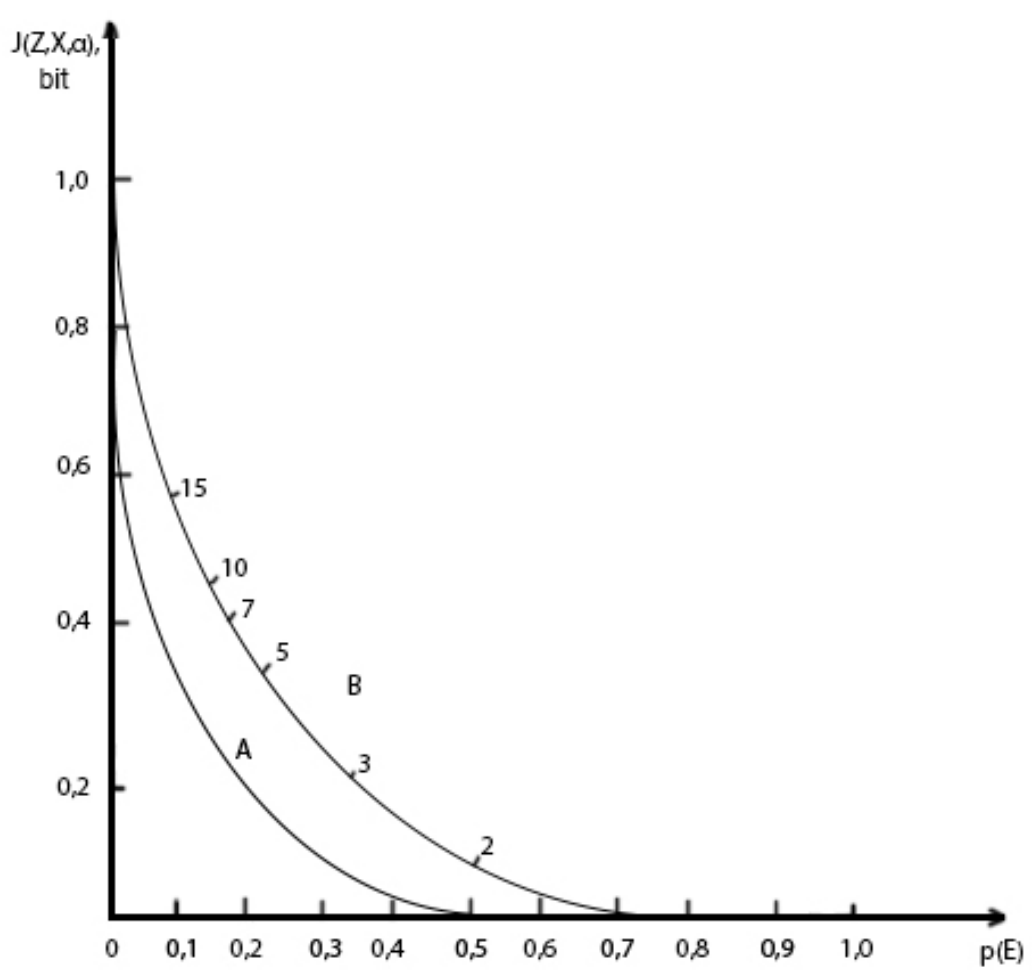

Figure 3 - Dependence of expected information on probability its losses in block grouping schemes transition probabilities

It can be seen from the Fig. 3 that the proposed large groupings of transitional probabilities allow essentially to reduce the losses of information. In this case the obtained results depend on the block schemes formation method and the method of their individual character informatively evaluation.

(C) Kupriyanov V. V., 2020

DOI 10.15588/1607-3274-2020-4-3

\section{DICUSSION}

As it evident from the Fig. 3, the application of the smaller groupings (with the lesser number of divisions) for the measuring $x_{i}$ no leads to an increase in the lower boundaries of the expected information. However, we should also note that for the intermediate values $x_{i}(7,10$, 
15) the relative losses of information, as well as the distortions в области их больших значений являются значительно меньшими. Therefore, the losses of information are decreased. For example, about the sevenmeasured scheme for the fifteen-measured scheme the loss of information is decreased to $0.5-0.6$ hit. And it is not little.

It is obvious, the block schemes are the most effective than the discrete schemes. At the same time, from the Fig. 2 can be seen that the widening of the discrete binary scheme to quinary scheme affords the gain in reduction of probability of information losses by more than 2.4 times, and to decimal scheme - by 3 times. Perhaps it is necessary to introduce a tolerance for distortion of information in measurement systems non less than two errors.

Formulas (8) and (9) it is possible to give an approximate estimate of the characteristics of information acquisition systems applicable to an equally probable distribution. But this is the distribution of implementations maximum value of Channon entropy and widely used in practice.

The closed analogue to the proposed method for determining the information additional losses is an Eentropy of Kolmagorov [4]. In contrast to the proposed in this paper, E-entropy measure it is connected with estimation only of information losses at sampling of real signals in time because of superimposition of E-network on initial set of possible continuous signals, as well as approximations of the measured function with unlimited spectrum using the limited spectrum model. The advantage of the schemes proposed in this paper is that there is no need to calculate the additional E-approximations and approximation errors of function spectra under noise conditions. The computational cost of the proposed schemes will be less than using of E-entropy.

Another near analogue to the proposed method is the method of determining the information characteristics of a discrete random sequence, which is described by the Markov process, with quantization by level and in time [1]. But his is found unsuitable for practical use. The main difficulty is in calculating the conditional Shannon entropy.

\section{CONCLUSIONS}

The urgent problem of mathematical support development is solved to automate the modeling at evaluating telemetrical information losses about geophysical processes in mines at conditions of noises.

The scientific novelty of obtained results is that the method of the additional losses of information evaluation which are caused by noise, measurement errors and transformations in the methane control subsystem is proposed. It determines the model for calculation the expected information lower boundaries at the given distortions. This allows to automate search for a whole set of schemes for obtaining information, which are characterized by different losses. This is turn reduce the information losses and provides introduction of data distortion tolerances in measurement systems to achieve an acceptable accuracy of measurements.

The practical significance of obtained results is that the software realizing the proposed schemes of information receipt is developed, as well as experiments to study their properties are conducted. The experimental results allow to recommend the proposed schemes for use in practice.

Prospects for further research are to study the proposed set of schemes for a broad class of practical problems and to build new measuring systems.

\section{REFERENCES}

1. Kavalerov G. I., Mandel'shtam S. M. Introduction to the Information Theory of Measurement. Moscow, énergiya, $1974,376 \mathrm{p}$

2. Shannon C. Information theory and cybernetics. In the Soviet Union, 1950.

3. Goldman S. Information Theory. Dover Pubs, 1968, 446 p.

4. Kolmagorov A. N., Tikhomov V. M. Entropy From Time Series Using Information-Theoretic Functionals. Milan palus, 1996, Vol. 2, No. 14, pp. 66-99.

5. Petrov B. N., Ulanov G. M., Petrov V. V., Ageyev V. M., Zaporozhets A. V., Uskov A. S., Kotchubievsky I. D., The Information Bases of the Theory of Feedback Control Systems. The Moscow Aviation Institute, 1972, Vol. 4, pp. 357.

6. Tarasenko F.P. Introduction to a Course on Information Theory. Tomsk, Tomsk University, 1963, $240 \mathrm{p}$.

7. Hiller F. S., Lieberman G. J. Introduction to stochastic models in operations research. New York, McGraw-Hill, 2010, 448 p. DOI: $10.1003 / 9781480612448$.

8. Lutsenko E.V. Matematicheskaya syshnost sistemnoyi teorii information, Kuban State Agrarian University named after I. T. Trubilina. Krasnodar, eISSN: 1990-4665

9. Bates, J.A.V. Significance of Information Theory to Neurophysiology, IRE Transactions on Information Theory, 1953, pp. 137-142

10. Wolfowitz J. Coding Theorems of Information Theory. Springer-Verlag, New York, 1978, 2rd

11. Kupriyanov V. V., Barannikova I. V. Metodologicheskie aspekty dispetcherskogo kontrolia gazovozdyshykh situatsij na uchastkakh Shakhty, Gornyi informatsionnoanaliticheskij Byulleten, 2016, No. 9, pp. 46-58.

12. Kuprianov V. V., Matskevich O., Bondarenko I. S. Parametricheskie i neparametricheskie modeli prognozirovania neshtatnykh situatsii $\mathrm{v}$ padzemnykh gornykh vyrabotnykh, Gornyi informatsionno-analyticheskiy byulleten, 2018, No. 3, pp. 200-207. DOI:10.25018/0236-1493-2018-3-0200-207.

13. Kupriyanov V. V., Gerasimov V.S. The ways of increase of reliability of the processing and transmission of information in automated control systems, Cornell University Library. USA, Itaka, state New York. Achives.org: cluster Information Theory, 2017, pp. 114-117. DOI:10.1145/1273496.2017 117.

14. Kupriyanov V.V. Vybor inervalov oprosa apparatury kontrolia metana $\mathrm{v}$ ugol'nykh shakhatakh, Informatsionnye Tekhnologii. Problemy $i$ Resheniia. Sed'maia Mezhdynarodnaia konferentsiia. Ufa, 21-24 Majia, trudy Ufa, Ufimskiy gosudarstvenniy tekhnicheskiy universitet, 2019, pp. 33-37.

15. Van der Zijpp N. J., Bovy H. L. Driver information acquisition behavior. A modeling approach, Automotive Technol- 
ogy and Automation:27th International Symposium ISATA, Aachen, Germany, 31st October-4th November,1994, proceedings. Croydon, Automotive Automation Society, England, 1994, pp. 113-120. ISBN 0947719652.

16. Shannon C. Weaver Warren The Mathematical Theory of Communication. University of Illinois Press, 1963, ISBN 0252-72548-4

17. Kullback S. Information Theory and Statistics. Dover Publications; New edition edition, July 7, 1997, 423 p.
18. Chaitin G. J. Information theoretical limitations of formal systems, J.Assoc. Comp, 1974, 21, pp. 403-424.

19. Bellman R. Dynamic Programming. Dover Publications; Reprint edition, 2003, $384 \mathrm{p}$.

20. Himmelblau D. Process analysis by statistical methods. Wiley, 1970, $463 \mathrm{p}$.

Received 17.05.2020 Accepted 21.09.2020

УДК 622.831: $622.273 .21(091)$

ОЦНКА ТЕЛЕМЕТРИЧНОЇ ІНФОРМАЦЇ̈ ПРО ГЕОФІЗИЧНІ ПРОЦЕССИ В УМОВАХ ШУМУ

Купріянов В. В. - д-р техн. наук, професор, кафедра автоматизованих систем управління Національного дослідницького технологічного університету «МІСіС», Москва, Росія.

\section{АНОТАЦІЯ}

Актуальність. Розглянуто задачу мінімізації втрат інформації при дискретному вимірюванні вмісту метану в період виймання вугілля у вугільних шахтах. Об'єктом дослідження була методика оцінки втрат телеметричної інформації про геофізичних процесах в шахтах в умовах шумів. Мета роботи - створення набору дискретних і блокових схем отримання інформації для оцінки ії втрат при наявності спотворень на основі інформаційного підходу.

Метод. Подані результати дослідження методики розв'язання задачі мінімізації втрат інформації при вимірюванні вмісту метану в вугільних шахтах. Запропоновано міру спотворень, що виникають при дискретному відображенні множини станів геофізичного процесу, в просторі вимірювань в умовах шумів і помилок в елементах подсистеми автоматизованого контролю метану. Поряд з цим заходом також запропонована модель для визначення нижньої границі очікуваної інформації при заданих викривленнях, заснована на рішенні оптимізаційної задачі. Досліджено характеристики деяких дискретних блокових схем отримання інформації. Запропоновані блокові схеми враховують угруповання значень перехідних ймовірностей по трьох, п’яти, семи, десяти і пятнадцятимірних варіантах. Варіюючи розмір угруповання в блоках, методика дозволяє отримувати різні рівні деталізації меж очікуваної інформації.

Результати. Розроблені схеми реалізовані програмно і досліджені під час вирішення завдання мінімізації втрат інформації при контролі вмістів метану у вугільних шахтах.

Висновки. Проведені експерименти підтвердили працездатність запропонованого математичного забезпечення і дозволяють рекомендувати його для використання на практиці при побудові $n$-мірних схем отримання інформації. Перспективи подальших досліджень можуть полягати в експериментальному дослідженні запропонованих схем на більшому комплекті практичних завдань різної природи, а також у створенні перспективних вимірювальних систем, заснованих на принципах інформаційного аналізу.

КЛЮЧОВІ СЛОВА: дискретна схема отримання інформації, спотворення, перехідна ймовірність, втрата інформації, шум.

УДК 622.831: 622.273.21 (091)

ОЦЕНКА ТЕЛЕМЕТРИЧЕСКОЙ ИНФОРМАЦИИ О ГЕОФИЗИЧЕСКИХ ПРОЦЕССАХ В УСЛОВИЯХ ШУМА

Куприянов В. В. - д-р техн. наук, профессор, кафедра автоматизированных систем управления Национального исследовательского технологического университета «МИСиС», Москва, Россия.

\section{АННОТАЦИЯ}

Актуальность. Рассмотрена задача минимизации потерь информации при дискретном измерении содержания метана в период выемки угля в угольных шахтах. Объектом исследования являлась методика оценки потерь телеметрической информации о геофизических процессах в шахтах в условиях шумов. Цель работы - создание набора дискретных и блочных схем получения информации для оценки ее потерь при наличии искажений на основе информационного подхода.

Метод. Представлены результаты исследования методики решения задачи минимизации потерь информации при измерении содержания метана в угольных шахтах. Предложена мера искажений, возникающих при дискретном отображении множества состояний геофизического процесса, в пространстве измерений в условиях шумов и ошибок в элементах подсистемы автоматизированного контроля метана. Наряду с этой мерой также предложена модель для определения нижней границы ожидаемой информации при заданных искажениях, основанная на решении оптимизационной задачи. Исследованы характеристики некоторых дискретных и блочных схем получения информации. Предложенные блочные схемы учитывают группировки значений переходных вероятностей по трех, пяти, семи, десяти и пятнадцатимерным вариантам. Варьируя размер группировки в блоках, методика позволяет получать различные уровни детализации границ ожидаемой информации.

Результаты. Разработанные схемы реализованы программно и исследованы при решении задачи минимизации потерь информации при контроле содержаний метана в угольных шахтах.

Выводы. Проведенные эксперименты подтвердили работоспособность предложенного математического обеспечения и позволяют рекомендовать его для использования на практике при построении n-мерных схем получения информации. Перспективы дальнейших исследований могут заключаться в экспериментальном исследовании предложенных схем на большем комплекте практических задач разной природы, а также в создании перспективных измерительных систем, основанных на принципах информационного анализа. 
КЛЮЧЕВЫЕ СЛОВА: дискретная схема получения информации, искажения, переходная вероятность, потеря информации, шум.

\section{ЛІТЕРАТУРА / ЛИТЕРАТУРА}

1. Kavalerov G.I. Introduction to the Information Theory of Measurement / G. I. Kavalerov, S. M. Mandelshtam. Moscow : énergiya, 1974. $-376 \mathrm{p}$.

2. Shannon C. Information theory and cybernetics / C. Shannon. - in the Soviet Union, 1950.

3. Goldman S. Information Theory / S. Goldman. - Dover Pubs., 1968. - 446 p.

4. Kolmagorov A.N. Entropy From Time Series Using Information-Theoretic Functionals / A. N. Kolmagorov, V. M. Tikhomov // Milan palus. - 1996 - Vol. 2, № 14. P. 66-99.

5. Petrov B.N. The Information Bases of the Theory of Feedback Control Systems / [B. N. Petrov, G. M. Ulanov, V. V. Petrov et all] // The Moscow Aviation Institute. 1972. - Vol. 4. - P. 3-57.

6. Tarasenko F. P. Introduction to a Course on Information Theory / F. P. Tarasenko. - Tomsk : Tomsk University, 1963. $-240 \mathrm{p}$.

7. Hiller F. S. Introduction to stochastic models in operations research /F. S. Hiller, G. J. Lieberman. - New York : McGraw-Hill, 2010. $\quad-\quad 448$ p. DOI: $10.1003 / 9781480612448$.

8. Lutsenko E. V. Matematicheskaya syshnost sistemnoyi teorii information // Kuban State Agrarian University named after I. T. Trubilina. - Krasnodar - eISSN: 1990-4665

9. Bates J. A. V. Significance of Information Theory to Neurophysiology // IRE Transactions on Information Theory. 1953. - P. 137-142.

10. Wolfowitz J. Coding Theorems of Information Theory / J. Wolfowitz. - Springer-Verlag, New York, 1978. - 2rd

11. Kupriyanov V.V. Metodologicheskie aspekty dispetcherskogo kontrolia gazovozdyshykh situatsij na uchastkakh Shakhty /V. V. Kupriyanov, I. V. Barannikova // Gornyi informatsionno-analiticheskij Byulleten. - 2016. - №9. P. 46-58.
12. Kuprianov V. V. Parametricheskie I neparametricheskie modeli prognozirovania neshtatnykh situatsii v padzemnykh gornykh vyrabotnykh / V. V. Kupriyanov, O. Matskevich, I. S. Bondarenko // Gornyi informatsionno-analyticheskiy byulleten. - 2018. - № 3. - P. 200-207. DOI:10.25018/0236-1493-2018-3-0-200-207.

13. Kupriyanov V. V. The ways of increase of reliability of the processing and transmission of information in automated control systems / V. V. Kupriyanov, V. S. Gerasimov // Cornell University Library. USA, Itaka, state New York. Achives.org: cluster Information Theory. - 2017. - P. 114 117. DOI:10.1145/1273496.2017 117.

14. Kupriyanov V. V. Vybor inervalov oprosa apparatury kontrolia metana v ugol'nykh shakhatakh / V. V. Kupriyanov // Informatsionnye Tekhnologii. Problemy i Resheniia. Sed'maia Mezhdynarodnaia konferentsiia, Ufa, 21-24 Majia: trudy Ufa: Ufimskiy gosudarstvenniy tekhnicheskiy universitet, 2019. - P. 33-37.

15. Van der Zijpp N. J. Driver information acquisition behavior. A modeling approach / N. J. Van der Zijpp, H. L. Bovy // Automotive Technology and Automation:27th International Symposium ISATA, Aachen, Germany, 31st October-4th November,1994:proceedings. - Croydon : Automotive Automation Society, England. - 1994. - P. 113-120. ISBN 0947719652.

16. Shannon C. The Mathematical Theory of Communication / C. Shannon, Weaver Warren. - Univesity of Illinois Press, 1963. - ISBN 0-252-72548-4

17. Kullback S. Information Theory and Statistics / S. Kullback. - Dover Publications; New edition edition. - July 7, 1997. - $423 \mathrm{p}$.

18. Chaitin G. J. Information theoretical limitations of formal systems / G. J. Chaitin // J. Assoc. Comp. - 1974. - 21. P. 403-424.

19. Bellman R. Dynamic Programming / R. Bellman. - Dover Publications; Reprint edition, 2003. - 384 p.

20. Himmelblau D. Process analysis by statistical methods /D. Himmelblau. - Wiley, 1970. - 463 p. 